\title{
Study on the Path of Increasing Farmers' Income from the Perspective of Income Structure
}

\author{
Yang zhen \\ International business school \\ Shannxi normal university \\ Xi'an China \\ 00665@163.com
}

\begin{abstract}
The strategy of rural revitalization has been put forward scientifically and reasonably. The increase of farmers' income is the basis of their affluence. From the perspective of income structure, which includes the business income, salary income, property income and transfer income, this paper studies farmers living in the countryside and farmers who move into cities. Therefore, finally it concludes some basic routes for two types of farmers to increase their income, and proposes some valuable views that will benefit the increase of farmers' income. The above four ways cannot work at the same time if the farmers want to maximize the benefits, but the income growth mechanism is interconnected. The reform of land ownership confirmation, land circulation, urban and rural household registration system is of great significance to the increase of farmers' income.
\end{abstract}

Keywords-Farmers' income; Income structure; The path; Increase

\section{INTRODUCTION}

The strategy of rural revitalization with foresight has been put forward in the 19th congress. The increase of farmers' income is the basis of their affluence. As farmers' incomes increase, they will have more resources to improve their quality of life. Traditional content in the study of increasing farmers' income is general, this article sticks to the perspective of income structure, business income, salary income and property income and transfer income, these four dimensions covers all the range of the farmers' income. This article research form the perspective of the overall farmers, trying to figure out the route of increasing four types of income, but in the objective circumstances, one family cannot have four kinds of income, operating income needs agricultural specialization and scale management, using the method of agricultural mechanization and modernization, then the agricultural efficiency will improve ,and operating income has the chance to grow, thus it is difficult to be employed by other organizations to get salary income. And farmers in the countryside can take part in the work of town enterprise or local industrial park to obtain salary income, then do not have the redundant brain and physical strength to get operating income. Although these four types of income may be obtained by farmers, the proportion of income may vary greatly from farmers in the countryside to farmers moving into city.

\section{RESEARCH STATUS}

\section{A. Foreign research}

Yasuyuki Todo\&Ryo Takahashi (2011) estimated the impact of farmers' field schools on agricultural income in rural Ethiopia. Farmer field schools are established with the association for forest conservation and forest management, which is funded by Japan. This paper uses the method of differential propensity score matching to correct the possible deviation due to the selection of participants. By attending farmer field schools, farmers' real per capita income increased by about $\$ 60$ to $\$ 160$, the equivalent of, or more than, the average per capita income before the program. There is evidence that the sharp increase in income is due to the introduction of new agricultural measures, such as new techniques taught and promoted in farmers' field schools [1]. Kumar (2017) in 2016-2017, pick up more than 100 households steadfastly in Omaha in Galveston area to test and implement intervention in natural resource management, using the integrated analysis tools for the proposed interventions in agriculture system modeling. Experiments on simple interventions, such as soil water retention and using the recommended level of nitrogen fertilizer, crops in the whole farm can increase net earnings about $7 \%$ and $12 \%$ respectively in normal and dry years, through replacing low yield cows and buffalo, intensive farming system, net income increased $20 \%$ to $50 \%$ in a normal year and 35\%-136\% income increased in dry years. These studies help to explore the systematic intensification of different situations to design better ways to improve farmers' income [2].

\section{B. Domestic research}

FeiYan He (2015) pointed out: we should face new challenges under the new normal state to increase the farmers' income, by fully excavating agricultural internal income potential and developing rural secondary and third industries' income space, widen the channel of the external rural income, increase the intensity of policy to increase the farmers' income, carry out economic policy to narrow the income gap between urban and rural residents under the new normal. It is pointed out that there are four ways to increase revenue. Firstly, we should cultivate and develop new agricultural management subjects and build a modern agricultural management system with Chinese characteristics. Secondly, increase policy support for supporting farmers benefiting farmers and alleviating their 
worries. Thirdly, advance the reform of rural land management system in an orderly manner and guide the orderly circulation of rural land management rights. Fourth, increase education investment in rural areas to improve farmers' comprehensive quality [3]. PengJun Li (2017) proposed that the development of agricultural tourism resources in poverty-stricken areas has natural advantages such as beautiful natural scenery, good ecological environment and rich national culture. The farmers in poor areas can increase their income by developing agricultural tourism resources: one path is to become a shareholder with resources, which including their own collective grassland, cultivated land, and forest, etc., the compensation can be transformed into equity. Poor people have no mortgage to get the operating funds, thus the government can provide financial support through the type of agricultural park collective construction, loan is converted into capital, paying out dividends on a regular basis according to the operation situation; the second route is to work in agricultural park. The third way is to start a business like a farm or specialize in service industry like characteristic souvenir business [4]. FuSheng Zeng (2017) proposed a new idea to develop new industrial and new business forms and solve the dilemma of increasing farmers' income. He pointed out that rural areas are not equal to agriculture, and rural areas should not only develop primary industries, but also develop rural agricultural products processing industry. According to international experience, when a country's per capita GDP exceeds $\$ 5,000$, its tourism consumption will enter a period of rapid growth. China's per capita GDP exceeded \$5,000 in 2011 and exceeded $\$ 8,000$ in 2015 . In the future, China will enter a channel of rapid growth of tourism consumption. It's important to support local powerful agricultural enterprises to extend the industrial chain and combine agricultural production with rural tourism; and encourage social capital to invest in leisure agriculture in accordance with various financing modes, including PPP mode, "Internet plus" mode and crowdfunding mode [5]. XueMei Liu (2017) summarized the natural environment factors that affect farmers' income: farmer own quality, policy factors, market factors, scale management, and technology factors and so on, and the empirical analysis shows that the farmers' income has a great relationship with above factors. through analysis on the main body behavior factors, finally it is concluded that :to promote countermeasures of increasing farmers' income in JILIN province ,the following four points shown below: first, to develop the farmer cooperative organization and constantly improve the quality of the farmers; Second, accelerate the industrial structure adjustment of JILIN province agriculture, promote the industrialization management; Third, improve the circulation of agricultural products; Fourth, develop JILIN province green organic high value-added agriculture to promote industrial integration [6].

\section{THE PATH OF INCREASING THE COUNTRYSIDE FARMERS}

\section{A. Operating income}

Advance the upgrade transformation of traditional industries like agriculture, forestry, husbandry and sideline fishing. The government can moderately raise the purchase price of agricultural products. It's important to improve agricultural innovation, competitiveness and total factor productivity. Competitiveness comes from high product quality, innovation is the diversity of agricultural product and meeting consumer demand, total factor productivity come from agricultural mechanization and modernization, the premise is farmland scale, farmers per capita cultivated land in China is very few, so promoting the land circulation matters, the farmers mainly depend on operating income can use the advantage of scale economy to obtain higher operating income, which is similar to the farmers in the west. Farmers who do not want to farm or move to cities can also receive land transfer income. As China has a large population, the average cultivated land occupied by each person is only 0.1 hectare, which is equivalent to one third of the world's per capita cultivated land. Per capita arable land is 0.53 hectares in the United States, China's per capita arable land area is equivalent to $1 / 5$ of America's per capita arable land area, assuming that the traditional per acre revenue was 1000 yuan per $\mathrm{Mu}$, if farmers cultivated $\mathrm{Mu}$ per capita number is $10 \mathrm{mu}$, the average annual income is ten thousand yuan, and the cost is relatively high, the actual annual income is far less than ten thousand yuan. If the number of $\mathrm{Mu}$ per capita is 50 , then the income per capita is fifty thousand yuan. At this time, agricultural science and technology measures can be used to realize large-scale operation, so as to reduce the expenditure of unit arable land and the advantage of scale economy will show up. At this time, farmers' income opportunities have increased to a large extent.

Increasing investment in science and technology, strengthening the introduction of technology, using mechanization and modernization of production methods, as well as e-commerce and modern logistics services, the operating income can be enhanced.

\section{B. Salary income}

For farmers, they should be hired to get salary income, those farmers choose to stay in countryside, if they want to find the work and save the expenditure, the working place should be near to their family, the economic organization form can be diversified like township enterprises, village enterprises, or collective enterprises. Comparatively speaking, the remaining peasants work to obtain wage income. The township enterprises can process farmers' agricultural product or other types. Through the comparative advantage of production, the township enterprises can compete with the suburb enterprises and keep a foothold in market. Improving farmers' salary income, the key is to improve the economic efficiency of township and village enterprises and build a good income distribution plan at the same time, realize the balance capital accumulation of township enterprises and the expenditure of farmer's salary. 
markets. Financial support, skill training and business quality are all essential conditions for starting a business. Strategy of 'Double Creations' can help to reduce the threshold of enterprise registration, by forming market supervision administration, all kinds of license registration conduction business and enterprise handling tax expenditure can be reduced very quickly, by pushing forward the tax cuts and rate reduction, thereby not only benefits entrepreneurs and innovators, but also help to increase farmer's operating income. In order to promote the increase of operating income of rural migrant farmers, certain preference policy can be made to the establishment of enterprises by local government.

The increase of operating income can be promoted by increasing skills training, providing financial support and strengthening entrepreneurial guidance.

\section{B. Salary income}

Farmers moving into middle or small city, then they will compete low-skilled workers, for those college students with rural background, they decide to live in the city and occupy themselves in work that need skilled workers, thus facing competition with high skilled labors. For those with low educational background and rural background, the relocation life is mainly engaged in low-skilled work, such as catering, logistics, environmental protection and other low-value-added work. Wage income is mainly affected by its own factors, industry factors and macro-economic situation. For college students study in urban with rural background, professional choice, skill and comprehensive quality will affect the salary income level, for the low-skilled farmers moving into city, relatively balanced revenues is formed in catering and other service industry, the income gap is affected by the overall supply and demand. Is there any difference between the income of the migrant farmers and that of the urban residents in the same post? There is no significant difference. As long as it is integrated into urban life, the income level of both migrant farmers and urban residents remains basically the same.

Salary income can be increased by improving the comprehensive quality of individuals, deepening the reform of income distribution, and raising the threshold of personal income tax and carrying out tax credit measures.

\section{Transfer income}

The resources of transfer income are government departments, farmers moving into city partly belong to vulnerable groups, and farmers are in big disadvantage in social security nowadays. Many Chinese farmers have the idea of homesick, they are newcomers of the city, thus need a period of time to adapt to city life, so they can't occupy themselves in production quickly, so the state and local government can give these farmers monetary or living subsidies. For college students study in urban with rural background, their economic foundation is weak, the local government should help to promote the university students' employment and promote rural college students moving into the city, the local government can provide a certain amount of policy support .Thus, the college students who have just graduated will gradually adapt to urban life . time. The college students study in urban with rural background should study the law and follow the rules of certain 
Transfer income can be increased by increasing financial support, subsidies to farmers in cities, and improving their social security.

\section{Property income}

Property income includes income from rental or sale of the assets such as securities. property income or the farmers moving into city, on the one hand, the income from the revenue generated by the rural land circulation process, the asset can be acquired rights then to sell or rent for a long time, also can be rural land compensation fees; on the other hand, bank deposits, stocks, funds and other financial assets can be the resources of property income.

Property income can be increased by deepening land reform, promoting land circulation, buying securities such as stocks, and investing in movable or immovable property.

\section{CONCLUSION}

This article first analyzes the research status at home and abroad, and combining with the objective reality of China, to research the problems of the farmers' income from the perspective of income structure, including operating income, salary income, property income and transfer income. Respectively research the route of increasing farmer's income in countryside and in city and come to some valuable conclusions: urbanization process benefit both countryside farmers and farmers moving into city; Professional skills are very important for new type of professional farmers or migrant workers. The reform of land ownership confirmation, land circulation, urban and rural household registration system is of great significance to the realization of urban and rural population mobility and the increase of farmer's income.

\section{REFERENCES}

[1] Yasuyuki Todo and Ryo Takahashi. Impact of Farmer Field Schools on Agricultural Income and Skills: Evidence from an Aid-Funded Project in Rural Ethiopia. Journal of International Development, 2013 (3): 362381 .

[2] Kumar, Shalander; Mamidanna, Sravya; Potential for Enhancing Farmer Income in Semi-Arid Telangana: A Multi-model Systems Approach. Agricultural Economics Research Review. 2017.300.

[3] FeiYan He. Research on the path to achieve new breakthroughs in farmers' income growth under new challenges [J]. China statistics 2015(04):10-11. (In Chinese)

[4] PengJun Li. Research on the development of agricultural tourism resources and the path of increasing farmers' income in poverty-stricken areas [J]. Agricultural economy, 2017(09):76-78. (In Chinese)

[5] FuSheng Zeng. Solving the dilemma of increasing farmers' income by developing new industry and new business model $[\mathrm{J}]$. Hunan BBS, 2017(05): 80-83+2. (In Chinese)

[6] XueMei Liu. Research on the path to increase farmers' income in JiLin province [J]. Agricultural economy,2017(08):64-66. (In Chinese) 